\title{
Effect of Moisture Regimes on Yield Attributes, Yield, Nutrient Uptake and Quality of Chickpea Cultivars (Cicer arietinium L.)
}

\author{
D. Swetha* and S.A. Hussain \\ Department of Agronomy, College of Agriculture, Acharya N.G. Ranga Agricultural University, \\ Rajendranagar, Hyderabad - 500 030, Telangana, India \\ *Corresponding author
}

\section{A B S T R A C T}

\begin{tabular}{|l|}
\hline K e y w o r d s \\
Chickpea, Irrigation \\
scheduling, IW/CPE \\
ratio, Yield attributes, \\
yield, NPK uptake, \\
$\begin{array}{l}\text { Protein content, } \\
\text { Quality parameter. }\end{array}$ \\
\hline Article Info \\
\hline $\begin{array}{l}\text { Accepted: } \\
\text { 10 July } 2017 \\
\text { Available Online: } \\
\text { 10 September } 2017\end{array}$ \\
\hline
\end{tabular}

Keywords

Chickpea, Irrigation scheduling, IW/CPE ratio, Yield attributes, yield, NPK uptake, Quality parameter

Article Info

Accepted:

Available Online:

10 September 2017

\section{Introduction}

Pulses are commonly known as food legumes which are secondary to cereals in production and consumption in India. Pulses are the most valuable and naturally occurring sources of protein, vitamins, minerals and calories. Pulses play an important role in Indian agriculture as they restore soil fertility by fixing atmospheric nitrogen (approximately $20 \mathrm{~kg} \mathrm{ha}^{-1}$ ) through their nodules. Some pulses are drought resistant and some are having erosion resisting property due to their deep root system and good ground coverage. Because of these good characters, pulses are called as 'marvel of nature' (Parihar and Sandhu, 1987).
Chickpea (Cicer arietinum L.) is one of the most important grain legumes and belongs to the family Leguminosae. It is a drought tolerant leguminous crop used in various foods in several developing countries including India as a source of highly digestible (70-90\%) dietary protein. Water is a crucial input for augmenting crop production towards sustainability in agriculture. Scientific water management aims to provide suitable soil moisture environment to the crop to obtain optimum yield commensurate with maximum economy in irrigation water and maintain soil productivity. 
Availability of moisture in the soil enhances the efficiency of applied nutrients. Any reduction of soil moisture at critical stages will considerably reduce the grain yield. Therefore, it is necessary to evaluate irrigation scheduling so as to realize highest yield attributes, yield, nutrient (NPK) uptake and quality parameter (protein) of chickpea cultivars.

\section{Materials and Methods}

A field experiment was conducted to during rabi, 2013-2014. The research work was carried out at College Farm, College of Agriculture, Rajendranagar, Hyderabad. The soil of the experimental field was sandy loam in texture with $\mathrm{pH}$ of 7.8. The soil was low in available nitrogen (226 kg ha ${ }^{-1}$ ), available phosphorus (18.5 kg ha $\mathrm{kg}^{-1}$ and medium in available potassium $\left(235 \mathrm{~kg} \mathrm{ha}^{-1}\right)$ contents. The experiment was laid out in a randomized block design (two factors) with one factor I: treatments of four moisture regimes viz., $\mathrm{I}_{1}$ (Rainfed), $\mathrm{I}_{2}$ (0.3 IW: CPE), I 3 (0.6 IW: CPE), $\mathrm{I}_{4}$ (0.9 IW: CPE) and factor II: varieties JG-11 and Annegiri and replicated thrice. Chickpea was sown after treating the seed with Rhizobium and were hand dibbled @ 2 seeds hill $^{-1}$ at a depth of $6 \mathrm{~cm}$ and sowing was carried out in N-S direction leaving $10 \mathrm{~cm}$ space between two hills with a row to row gap of $30 \mathrm{~cm}$. Immediately after sowing basal application of $\mathrm{N}-20, \mathrm{P}_{2} \mathrm{O}_{5}-50, \mathrm{~K}_{2} \mathrm{O}-40 \mathrm{~kg} \mathrm{ha}^{-1}$ was applied. Intercultural operations like weeding, irrigation, pruning, disease and insect management were done as per necessary.

Nitrogen content in grain samples of chickpea were estimated by modified micro Kjeldahl method after digesting the powdered plant sample with $\mathrm{H}_{2} \mathrm{SO}_{4}$ and $\mathrm{H}_{2} \mathrm{O}_{2}$ (Piper, 1966).This nitrogen content of grain samples was multiplied with a factor 6.25 and protein content of grain samples of chickpea was obtained (Piper, 1966).
The tri-acid digested plant samples were analysed for phosphorus content by Vanado molybdo phosphoric acid yellow colour method. The intensity of yellow colour developed was measured using Spectronic 20 D. The uptake of phosphorus was calculated by multiplying the phosphorus content with the respective dry matter production and expressed in $\mathrm{kg} \mathrm{ha}^{-1}$.

Potassium content of the diluted tri-acid digest was determined by using ELICO flame photometer and the uptake of potassium was estimated by multiplying the $\mathrm{K}$ content with the respective dry matter production and presented in $\mathrm{kg} \mathrm{ha}^{-1}$.

Yield attributes and yield were recorded at harvest. The data recorded were statistically analyzed duly following the analysis of variance technique for randomized block design as suggested by Panse and Sukhatme (1978).

\section{Results and Discussion}

The present investigation entitled "Effect of moisture regimes on yield attributes, yield, nutrient uptake and quality of chickpea (Cicer arietinum L.)" were carried out during rabi, 2013-2014 at College Farm, College of Agriculture, Rajendranagar, Hyderabad. The results of the investigation, regarding the chickpea on yield attributes, yield, NPK uptake and protein content have been presented in tables 1, 2 and 3.

\section{Yield attributes}

The maximum number of pods plant ${ }^{-1}$ (74.27 and 65.30 for JG-11 and Annegiri, respectively) was recorded with $\mathrm{I}_{3}$ (0.6 IW: CPE) treatment, whereas the lowest number of pods plant ${ }^{-1}$ (53.20 and 46.25 for JG-11 and Annegiri, respectively) was recorded under $\mathrm{I}_{1}$ (control). A further increase in the moisture regime failed to influence the 
number of pods plant ${ }^{-1}$ from 0.6-0.9 IW: CPE ratio as supported with results of Patel et al., (1988) and Mansur et al., (2010). This could be ascribed to the fact that moisture availability in the root zone increased the nutrient uptake which produces multiple physiological effects and to increase in net assimilation followed by source to sink of the photosynthates. Similar findings were reported by Singh and Dixit (1992), Dixit et al., (1993), Dabhi et al., (1998), Reddy and Ahlawat (1998), Kaushik and Chaubey (1999), Chandrasekhar and Saraf (2005) and Mustafa et al., (2008). The varieties significantly influenced the number of pods plant $^{-1}$. All the treatments differed significantly among themselves. $\mathrm{I}_{3}$ (74.27 pods plant ${ }^{-1}$ of JG-11) recorded highest number of pods which is at par with $\mathrm{I}_{4}$ treatment (70.17 pods plant ${ }^{-1}$ of JG-11), while $\mathrm{I}_{1}$ put forth the lowest number of pods $(53.20$ pods plant ${ }^{-1}$ of JG-11). JG-11 recorded significantly higher pods (74.27 pods plant ${ }^{-1}$ ) when compared with Annegiri (61.52 pods plant $\left.^{-1}\right)$. Similar findings were reported by Naik et al., (2012) and Rao et al., (2012).

No.of seed pod $^{-1}$ in chickpea showed that irrigation schedules, varieties and their interactions have no significant effect. These results are in conformity with those of Dixit $e t$ al., (1993), Reddy and Ahlawat (1998), Kaushik and Chaubey (1999), Chandrasekhar and Saraf (2005).

Irrigation treatment $\mathrm{I}_{3}$ recorded significantly higher test weight ( $24 \mathrm{~g}$ and $20.83 \mathrm{~g}$ for JG-11 and Annegiri, respectively) as compared to the rest of the irrigation treatments and was followed, in decreasing order, by $\mathrm{I}_{4}(23.84 \mathrm{~g}$ and $20.2 \mathrm{~g}$ for JG-11 and Annegiri, respectively), $\mathrm{I}_{2}$ (21.42 $\mathrm{g}$ and $18.13 \mathrm{~g}$ for JG11 and Annegiri, respectively) and $\mathrm{I}_{1}(19.04 \mathrm{~g}$ and $17.23 \mathrm{~g}$ for JG-11 and Annegiri, respectively) treatments, respectively. The treatment $\mathrm{I}_{4}$ and $\mathrm{I}_{3}$ were on par with each other and were significantly superior to $I_{1}$ treatment which recorded the lowest test weight. The increase in test weight with the increase in irrigation frequency might be due to better growth of the crop, efficient dry matter partitioning and better translocation to the sink, leading to the formation of large sized seeds. In the case of highest irrigation level i.e. $\mathrm{I}_{4}$ treatment, the decrease might be due to too frequent irrigation leading to poor grain filling when compared with $\mathrm{I}_{3}$. These results were in conformation with those of Patel et al., (1988), Singh and Dixit (1992), Chandrasekhar and Saraf (2005). The variety JG-11 has recorded highest test weight (24 g) when compared with Annegiri (20.83 g). Similar results were recorded by of Rao et al., (2012). But the interaction effect of varied moisture regime and varieties was nonsignificant (Naik et al., 2012).

\section{Grain yield}

The highest grain yield was obtained when irrigation was scheduled at an IW: CPE ratio of $0.6\left(I_{3}\right)\left(1882 \mathrm{~kg} \mathrm{ha}^{-1}\right.$ and $1655 \mathrm{~kg} \mathrm{ha}^{-1}$ for JG-11 and Annegiri, respectively), but it was on par with $\mathrm{I}_{4}$ (IW: CPE-0.9) (1722 $\mathrm{kg} \mathrm{ha}^{-1}$ and $1542 \mathrm{~kg} \mathrm{ha}^{-1}$ for JG-11 and Annegiri, repectively) treatment and $\mathrm{I}_{4}$ is on par with $\mathrm{I}_{2}$ (1567 kg ha ${ }^{-1}$ and $1322 \mathrm{~kg} \mathrm{ha}^{-1}$ for JG-11 and Annegiri, respectively). The higher grain yield with more frequent irrigation might be accounted for their favorable influence on the growth characters (plant height and number of branches respectively) and yield attributing characters (no. of pods plant ${ }^{-1}$ and test weight, respectively). In case of $\mathrm{I}_{4}$ treatment which provide maximum frequency of irrigation (four irrigations), the decrease in grain yield as compared to $\mathrm{I}_{3}$ treatment might be due to frequent irrigations leading to relatively lesser seed filling as it was evident from the data on test weight. Similar findings were reported by Palled et al., (1985), Chandrasekhar and Saraf (2005). With an increment in the no. of pods 
plant $^{-1}$ and test weight, the grain yield was significantly increased. The JG-11 variety recorded significantly higher grain yield (1882 kg ha $\mathrm{kg}^{-1}$ at $0.6 \mathrm{IW}$ : CPE ratio) as compared to Annegiri (1655 kg ha ${ }^{-1}$ at 0.6 IW:
CPE ratio). These results were in conformity with Naik et al., (2012), Rao et al., (2012). Interaction effect between irrigation levels and varieties was non-significant with regard to the grain yield.

N Uptake of chickpea grain influenced by varied moisture regime

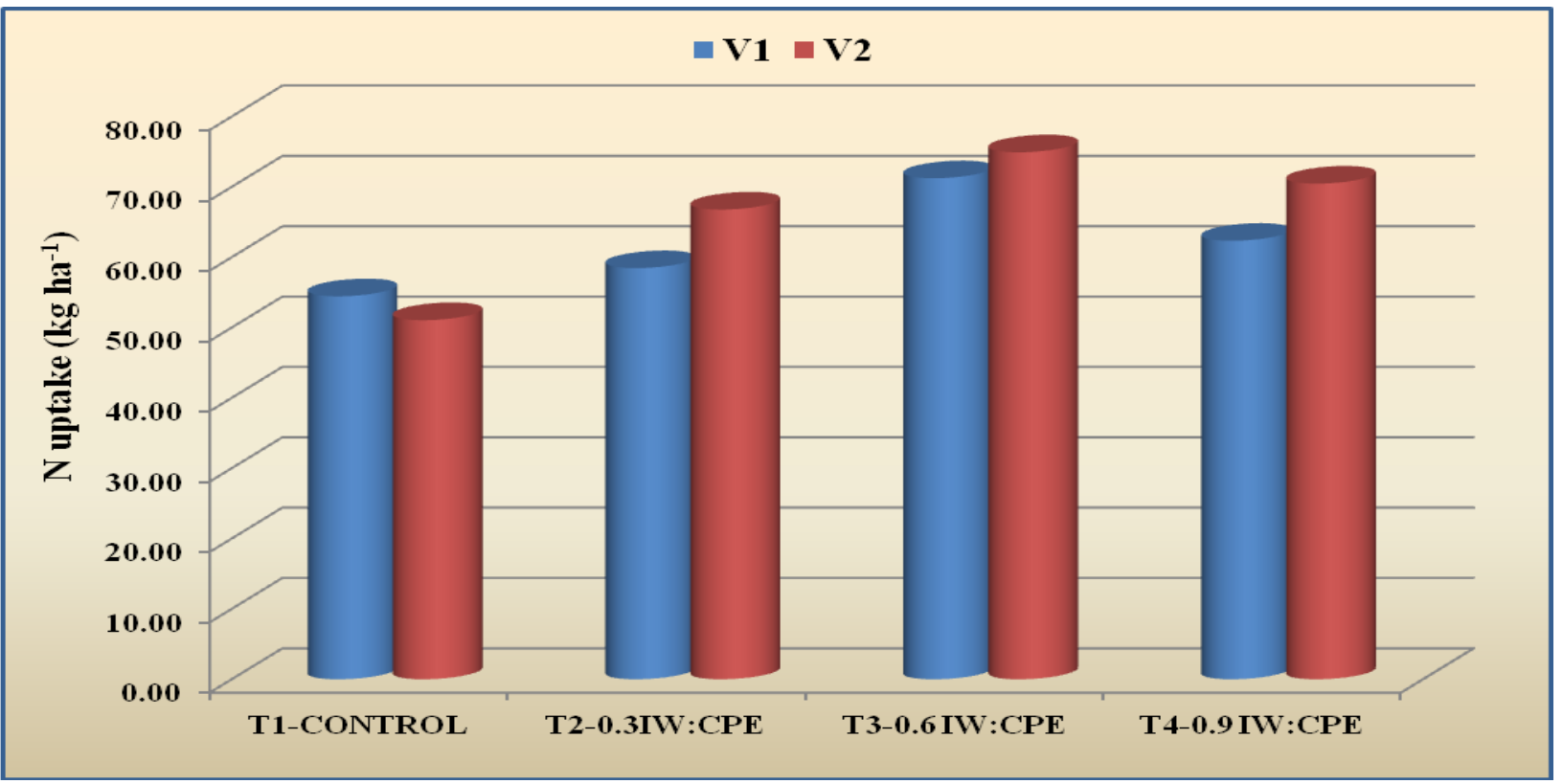

IW: CPE- Irrigation Water: Cumulative Pan Evaporation, V1- JG-11, V2-Annegiri

\section{P Uptake of chickpea grain influenced by varied moisture regime}

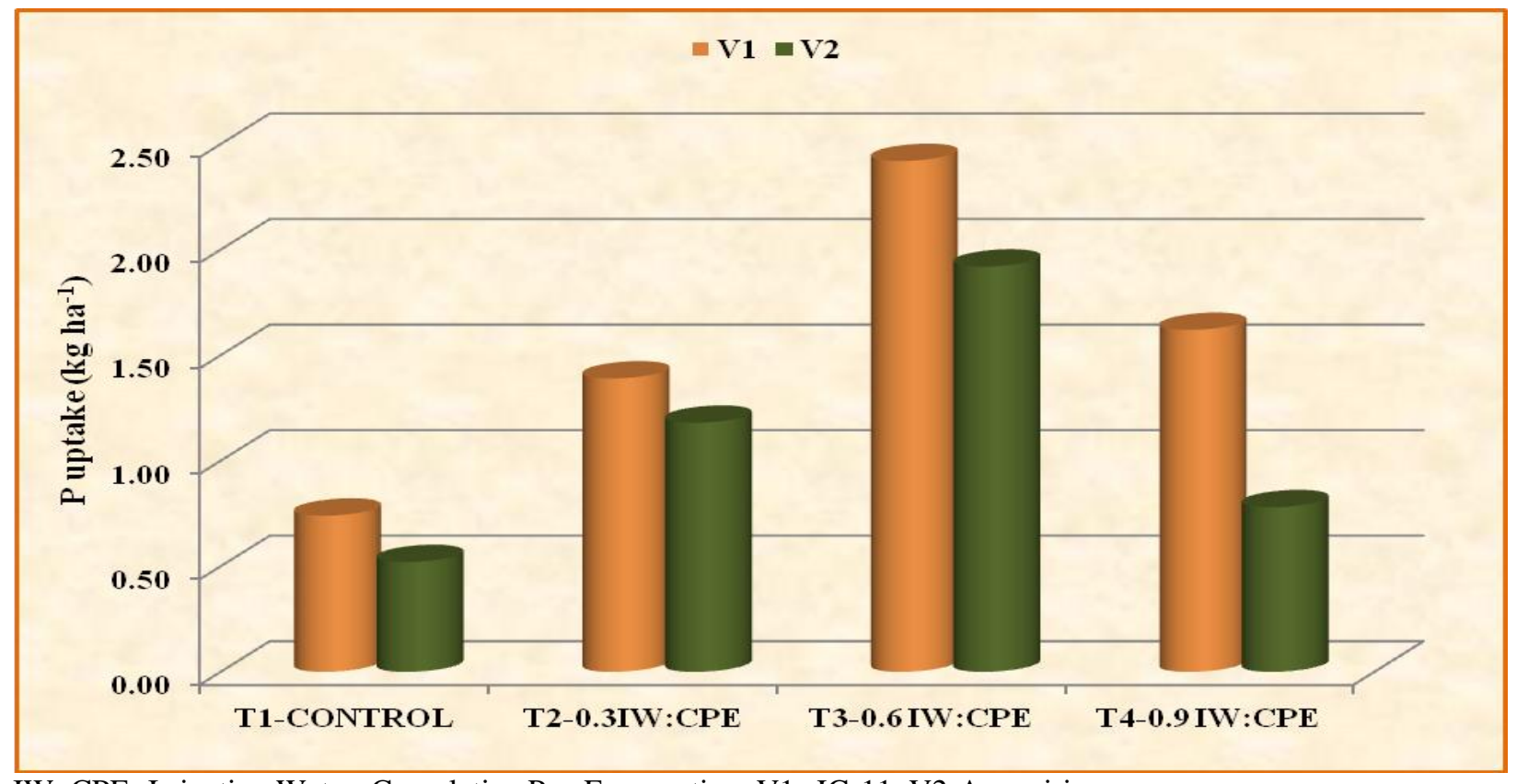

IW: CPE- Irrigation Water: Cumulative Pan Evaporation, V1- JG-11, V2-Annegiri 


\section{K Uptake of chickpea grain influenced by varied moisture regime}

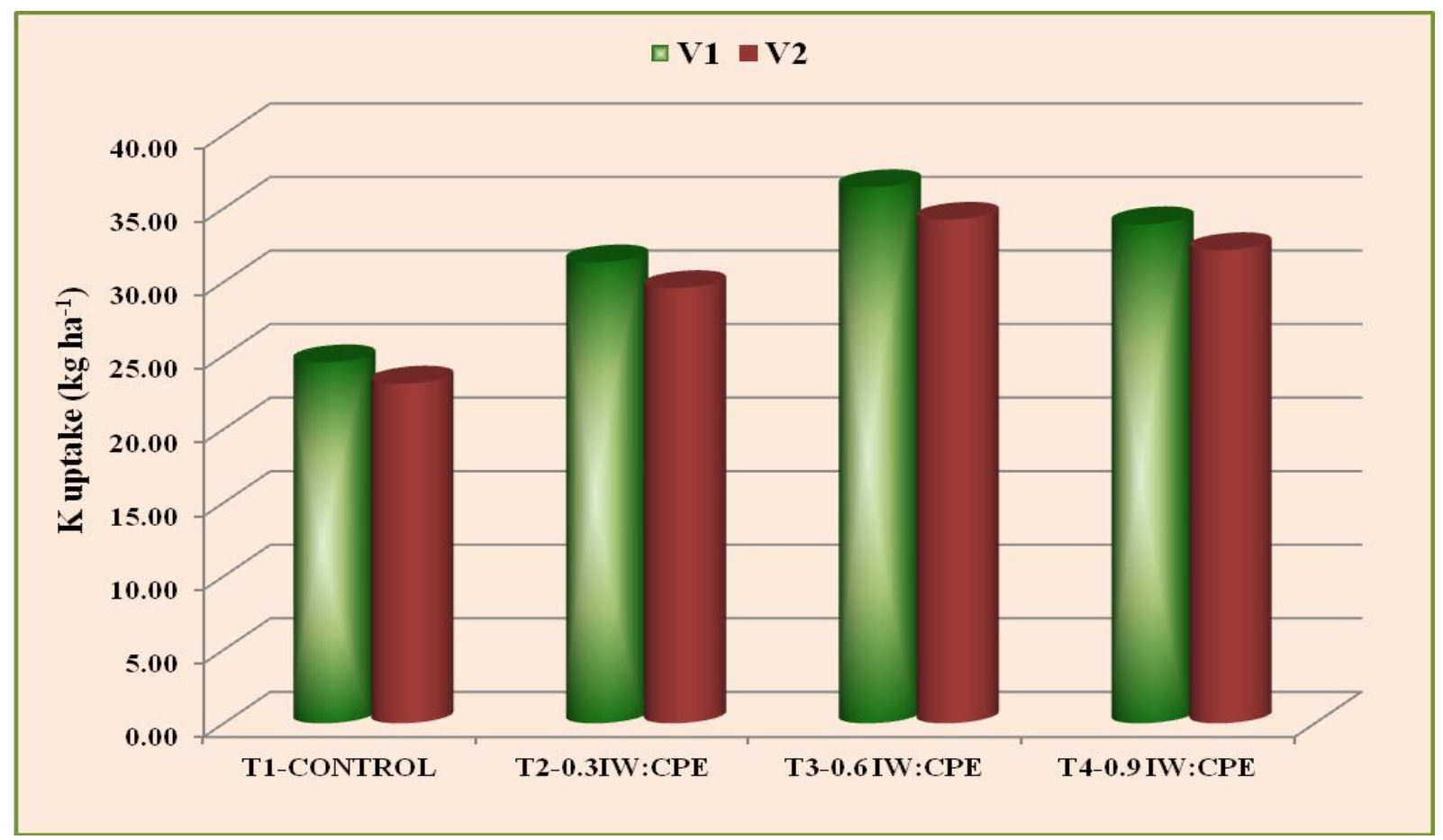

IW: CPE- Irrigation Water: Cumulative Pan Evaporation, V1- JG-11, V2-Annegiri

Quality parameter of chickpea grain influenced by varied moisture regime

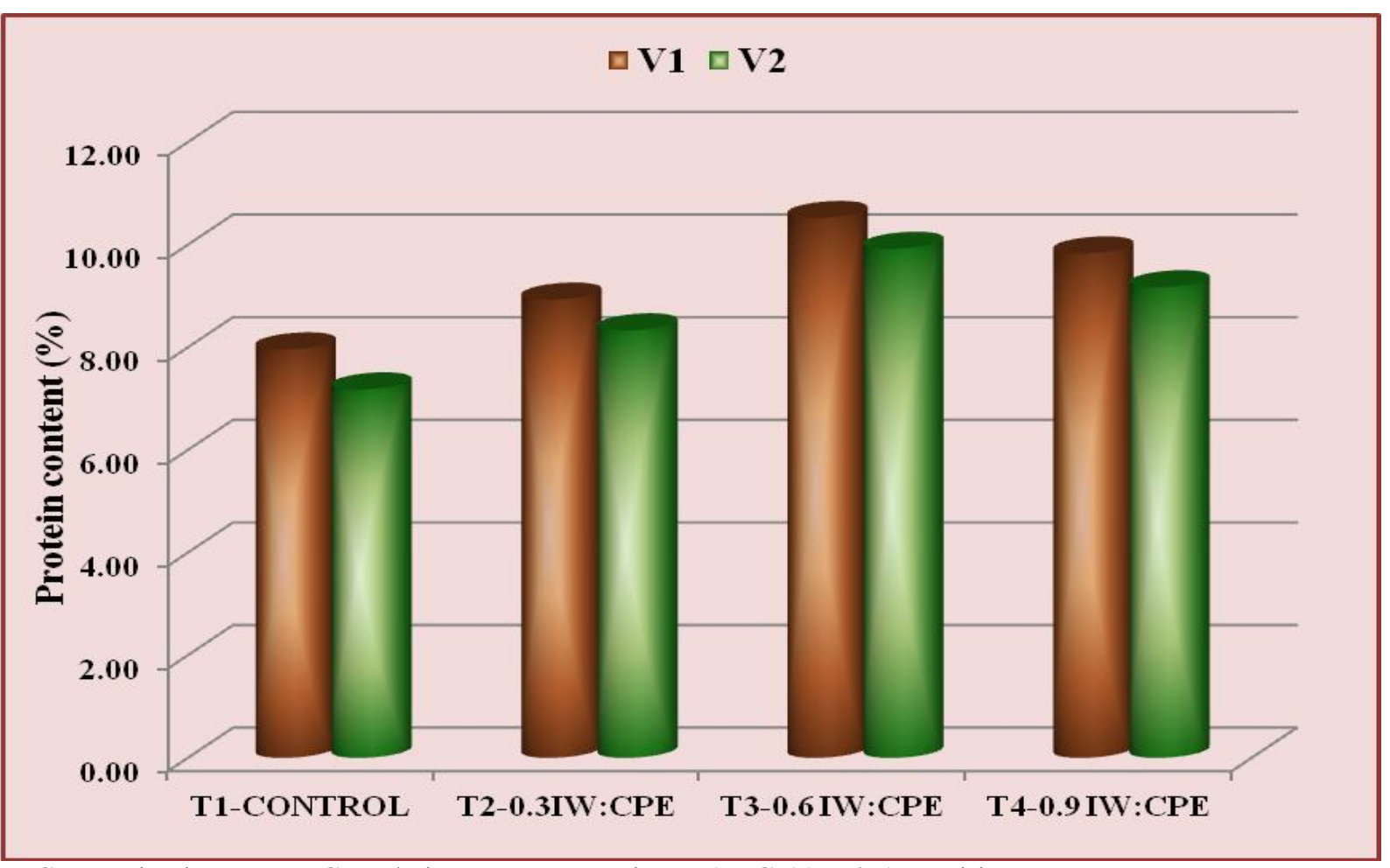

IW: CPE- Irrigation Water: Cumulative Pan Evaporation, V1- JG-11, V2-Annegiri 
Table.1 Yield attributes of chickpea varieties influenced by varied moisture regime

\begin{tabular}{|c|c|c|c|c|c|c|c|c|c|}
\hline \multirow[t]{2}{*}{ TREATMENTS } & \multicolumn{3}{|c|}{ No. of pods plant ${ }^{-1}$} & \multicolumn{3}{|c|}{ No. of seeds pod ${ }^{-1}$} & \multicolumn{3}{|c|}{ Test weight (g) } \\
\hline & V1 & V2 & Mean & V1 & V2 & Mean & V1 & $\mathrm{V} 2$ & Mean \\
\hline T1-CONTROL & 53.20 & 46.25 & 49.73 & 1.00 & 1.07 & 1.03 & 19.04 & 17.23 & 18.14 \\
\hline T2-0.3IW: CPE & 62.07 & 54.13 & 58.10 & 1.00 & 1.00 & 1.00 & 21.42 & 18.13 & 19.78 \\
\hline T3-0.6 IW: CPE & 74.27 & 65.30 & 69.78 & 1.00 & 1.07 & 1.03 & 24.00 & 20.83 & 22.42 \\
\hline T4-0.9 IW: CPE & 70.17 & 61.52 & 65.85 & 1.13 & 1.00 & 1.07 & 23.84 & 20.2 & 22.02 \\
\hline Mean & 63.18 & 55.23 & 59.20 & 1.03 & 1.03 & 1.03 & 22.08 & 19.10 & 20.59 \\
\hline & $\mathrm{SE}(\mathrm{m})$ & $\mathrm{CD}$ & & $\mathrm{SE}(\mathrm{m})$ & $\mathrm{CD}$ & & $\mathrm{SE}(\mathrm{m})$ & $\mathrm{CD}$ & \\
\hline Factor A & 1.64 & 4.97 & & 0.02 & NS & & 0.55 & 1.68 & \\
\hline Factor B & 2.32 & 7.03 & & 0.03 & NS & & 0.78 & 2.37 & \\
\hline Factor $(\mathrm{A} \times \mathrm{B})$ & 3.28 & NS & & 0.04 & NS & & 1.11 & NS & \\
\hline
\end{tabular}

IW: CPE- Irrigation Water: Cumulative Pan Evaporation

V1- JG-11, V2-Annegiri, Factor A-Varieties, Factor B- Irrigation levels

Table.2 Yield of chickpea varieties influenced by varied moisture regime

\begin{tabular}{|c|c|c|c|c|c|c|c|c|c|}
\hline \multirow[t]{2}{*}{ TREATMENTS } & \multicolumn{3}{|c|}{ Grain yield $\left(\mathrm{kg} \mathrm{ha}^{-1}\right)$} & \multicolumn{3}{|c|}{ Haulm yield $\left(\mathrm{kg} \mathrm{ha}^{-1}\right)$} & \multicolumn{3}{|c|}{ Harvest index (\%) } \\
\hline & V1 & $\mathrm{V} 2$ & Mean & V1 & V2 & Mean & V1 & $\mathrm{V} 2$ & Mean \\
\hline T1-CONTROL & 1245 & 1008 & 1127 & 618 & 451 & 535 & 65.02 & 68.62 & 66.82 \\
\hline T2-0.3IW: CPE & 1567 & 1323 & 1445 & 750 & 583 & 667 & 64.33 & 70.73 & 67.53 \\
\hline T3-0.6 IW: CPE & 1882 & 1655 & 1769 & 893 & 794 & 844 & 65.93 & 65.97 & 65.95 \\
\hline T4-0.9 IW: CPE & 1722 & 1542 & 1632 & 822 & 657 & 740 & 65.77 & 67.09 & 66.43 \\
\hline Mean & 1604 & 1382 & 1493 & 771 & 621 & 696 & 65.26 & 68.10 & 66.68 \\
\hline & $\mathrm{SE}(\mathrm{m})$ & $\mathrm{CD}$ & & $\mathrm{SE}(\mathrm{m})$ & $\mathrm{CD}$ & & $\mathrm{SE}(\mathrm{m})$ & $\mathrm{CD}$ & \\
\hline Factor A & 72.05 & 218.55 & & 29.93 & 90.81 & & 1.51 & NS & \\
\hline Factor B & 101.90 & 309.07 & & 42.33 & 128.42 & & 2.13 & NS & \\
\hline Factor $(\mathrm{A} \times \mathrm{B})$ & 144.10 & NS & & 59.87 & NS & & 3.01 & NS & \\
\hline
\end{tabular}

IW: CPE- Irrigation Water: Cumulative Pan Evaporation+

V1- JG-11, V2-Annegiri, Factor A-Varieties, Factor B- Irrigation levels 
Table.3 NPK uptake and protein content of chickpea grain influenced by varied moisture regime

\begin{tabular}{|c|c|c|c|c|c|c|c|c|c|c|c|c|}
\hline \multirow[t]{2}{*}{ TREATMENTS } & \multicolumn{3}{|c|}{ N uptake (kg ha $\left.{ }^{-1}\right)$} & \multicolumn{3}{|c|}{ P uptake (kg ha $\left.{ }^{-1}\right)$} & \multicolumn{3}{|c|}{ K uptake $\left(\mathrm{kg} \mathrm{ha}^{-\mathbf{1}}\right)$} & \multicolumn{3}{|c|}{ Protein content $(\%)$} \\
\hline & V1 & $\mathbf{V 2}$ & Mean & V1 & $\mathbf{V 2}$ & Mean & V1 & $\mathbf{V 2}$ & Mean & V1 & $\mathbf{V} 2$ & Mean \\
\hline T1-CONTROL & 51.06 & 54.45 & 52.76 & 0.32 & 0.22 & 0.27 & 24.54 & 23.09 & 23.82 & 19.13 & 18.67 & 18.90 \\
\hline T2-0.3IW: CPE & 66.78 & 58.45 & 62.62 & 0.45 & 0.42 & 0.37 & 31.33 & 29.58 & 30.46 & 22.50 & 22.00 & 23.30 \\
\hline T3-0.6 IW: CPE & 74.92 & 71.23 & 73.08 & 0.51 & 0.55 & 0.53 & 36.44 & 34.23 & 35.34 & 24.90 & 24.70 & 24.80 \\
\hline T4-0.9 IW: CPE & 70.47 & 62.34 & 66.41 & 0.25 & 0.35 & 0.30 & 33.92 & 32.16 & 33.04 & 23.00 & 22.90 & 22.30 \\
\hline \multirow[t]{2}{*}{ Mean } & 65.81 & 61.62 & 63.71 & 0.38 & 0.39 & 0.38 & 31.56 & 29.77 & 30.66 & 22.82 & 22.50 & 22.66 \\
\hline & $\mathrm{SE}(\mathrm{m})$ & $\mathrm{CD}$ & & $\mathrm{SE}(\mathrm{m})$ & $\mathrm{CD}$ & & $\mathrm{SE}(\mathrm{m})$ & $\mathrm{CD}$ & & $\mathrm{SE}(\mathrm{m})$ & $\mathrm{CD}$ & \\
\hline Factor A & 1.11 & 3.36 & & 0.04 & NS & & 0.46 & 1.39 & & 0.63 & NS & \\
\hline Factor B & 1.57 & 4.76 & & 0.06 & NS & & 0.65 & 1.97 & & 0.89 & 2.61 & \\
\hline Factor $(\mathrm{A} \times \mathrm{B})$ & 2.22 & 6.73 & & 0.08 & NS & & 0.92 & 2.79 & & 1.25 & NS & \\
\hline
\end{tabular}

IW: CPE- Irrigation Water: Cumulative Pan Evaporation,V1- JG-11, V2-Annegiri, Factor A-Varieties, Factor B- Irrigation levels 


\section{Haulm yield}

Irrigation level $\mathrm{I}_{3}$ recorded the maximum haulm yield $\left(893 \mathrm{~kg} \mathrm{ha}^{-1}\right.$ and $794 \mathrm{~kg} \mathrm{ha}^{-1}$ for JG-11 and Annegiri, repectively), but was on par with $\mathrm{I}_{4}$ treatment $\left(822 \mathrm{~kg} \mathrm{ha}^{-1}\right.$ and $657 \mathrm{~kg}$ $\mathrm{ha}^{-1}$ for JG-11 and Annegiri, repectively). The increase in haulm yield with increased in irrigation frequency of irrigation might be accounted for high vegetative growth and dry matter production. Similar findings were reported by Dabhi et al., (1998) and Singh et $a l$. , (2005). The varieties significantly differ among themselves higher haulm yield was obtained with JG-11 variety $\left(893 \mathrm{~kg} \mathrm{ha}^{-1}\right)$ when compared with Annegiri (794 $\mathrm{kg} \mathrm{ha}^{-1}$ ). Similar findings were reported by Rao et al., (2012). Interaction effect of irrigation schedules and varieties has shown inconsistence which resulted in nonsignificant.

Form for going discussion, it can be concluded that, Irrigation scheduled at 0.6 IW: $\mathrm{CPE}\left(\mathrm{I}_{3}\right)$ produced significantly higher yield attributes and grain and haulm yields of chickpea but it was on par with 0.9 IW: CPE $\left(\mathrm{I}_{4}\right)$. The JG-11 variety has produced higher grain yield than Annegiri.

\section{NPK uptake (at harvest)}

Varied moisture regime had a significant influence on $\mathrm{N}, \mathrm{P}_{2} \mathrm{O}_{5}$ and $\mathrm{K}_{2} \mathrm{O}$ uptake of plants at harvest (table 3).

Increasing irrigation frequency resulted in increase in total uptake of $\mathrm{N}, \mathrm{P}_{2} \mathrm{O}_{5}$ and $\mathrm{K}_{2} \mathrm{O}$ (table 3). The highest uptake was obtained with $\mathrm{I}_{3}$ treatment. With additional increase in the frequency of irrigation upto $\mathrm{I}_{4}$, nitrogen uptake was lower due to leaching losses and lower yield levels. The lowest uptake was obtained with $\mathrm{I}_{1}$ (control) treatment. But as a whole, the increase in irrigation frequency resulted in higher solubility of nutrients and higher uptake. Meager water supply or excessive irrigation can result in unavailability or leaching of a major part of nutrients resulting in insufficiency of nutrient and low yields. Proper water management will hold these losses to a bare minimum. Likewise, the amount and movement of water in soil influence the availability of nutrients to plant roots. Similar findings were reported by Roy and Tripathi (1985), Dixit et al., (1993), Srivastava and Srivastava (1994), Reddy and Ahlawat (1998).

The highest $\mathrm{K}$ uptake was obtained with $\mathrm{I}_{3}$ treatment. With additional increase in the frequency of irrigation upto $\mathrm{I}_{4}, \mathrm{P}$ uptake has been not influenced by irrigation.

Varieties and interaction effect of varied moisture regime and varieties has shown significant effect. Among varieties, JG-11 has showed more $\mathrm{N}$ and $\mathrm{K}$ uptake but $\mathrm{P}$ uptake remained non-significant.

\section{Quality Parameter}

\section{Protein content (\%)}

It was evident from the data in (table 3) that the protein content of chickpea was significantly influenced by varied moisture regime. The treatment $\mathrm{I}_{3}$ (0.6 IW: CPE) recorded (24.9\% and $24.7 \%$ for JG-11 and Annegiri, respectively) significantly higher protein content as compared to $\mathrm{I}_{1}$ - control $(19.13 \%$ and $18.67 \%$ for JG-11 and Annegiri, respectively), $\mathrm{I}_{2}-0.3$ IW: CPE (22.50\% and $22 \%$ for JG-11 and Annegiri, respectively) and $\mathrm{I}_{4}-0.9 \mathrm{IW}$ : CPE (23\% and 22.9\% for JG-11 and Annegiri, respectively). The lowest protein content was observed in $\mathrm{I}_{1}$ (control) treatment. This finding is conformity with those of Dixit et al., (1993).

The varieties as well as the interaction effect of irrigation schedules and varieties has no 
consistency and finally results in insignificant data.

In view of the experimental results obtained during the present investigation, Irrigation scheduled at 0.6 IW: $\mathrm{CPE}\left(\mathrm{I}_{3}\right)$ produced significantly higher yield attributes and grain and haulm yields of chickpea but it was on par with $0.9 \mathrm{IW}$ : CPE $\left(\mathrm{I}_{4}\right)$. The JG-11 variety has produced higher grain yield than Annegiri. The total $\mathrm{N}, \mathrm{P}_{2} \mathrm{O}_{5}$ and $\mathrm{K}_{2} \mathrm{O}$ uptake was lowest with $\mathrm{I}_{1}$ (rainfed) and increasing frequency of irrigation resulted in higher uptake of nutrient. The treatment 0.6 IW: CPE $\left(\mathrm{I}_{3}\right)$ has recorded highest uptake. Genotype variation was not seen. Protein content (\%) was highest in $0.9 \mathrm{IW}$ : CPE $\left(\mathrm{I}_{4}\right)$ but it was on par with $0.6 \mathrm{IW}$ : $\mathrm{CPE}\left(\mathrm{I}_{3}\right)$. Treatment $\mathrm{I}_{4}$ is significantly superior to $\mathrm{I}_{1}$ (rainfed) and $\mathrm{I}_{2}(0.3$ IW: CPE). The varieties have no influence on protein content.

\section{References}

Chandrasekhar, K., and Saraf, C.S. 2005. Influence of irrigation and fertility levels on growth and yield of late sown chickpea (Cicer arietinium L.). The Andhra Agricultural Journal. 52(3\&4): 322-325.

Dabhi, B.M., Patel, J. C and Solanki, R. M. 1998. Response of summer greengram to irrigation methods and varying moisture regimes. Legume Research. 21(2): 96-100.

Dixit, J. P., Dubey, O. P and Soni, N. P. 1993. Effect of sowing date and irrigation on yield and nutrient uptake by chickpea cultivars under Tawa Command Area.. Indian Journal of Agronomy. 38(1): 227-231.

Dixit, J.P., Pillai, P.V.A and Namdeo, K.N. 1993. Response of chickpea and planting date and irrigaton schedule.
Indian Journal of Agronomy. 38(1): 121-123.

Kaushik, M.K., and Chaubey, A.K. 1999. Studies on irrigation requirement of chickpea (Cicer arietinium L.). Indian Journal of Agronomy.44(2): 367-369.

Mustafa, M.N., Karuna Sagar, G., Chandrika. V and Reddy, P.M. 2008. Growth and yield of chickpea as influenced by irrigation and nutrient management. Legume Research. 31(3): 221-223.

Naik, V., Pujari, B.T., Halepyati, A.S and Koppalkar, B.G. 2012. Growth and yield of late sown chickpea as influenced by irrigation methods, genotypes and planting densities. Karnataka Journal of Agricultural Science. 25(2): 267-269.

Palled, Y.B., Chandrashekharaiah, A.M and Radder, G.D. 1985. Response of bengalgram to moisture stress. Indian Journal of Agronomy. 30(1): 104-106.

Panse, V.G., and Sukhatme, P.V.1978. Statistical Methods for Agricultural Workers. 3rd edn, ICAR, New Delhi, p.347.

Parihar, S.S., and Sandhu, B.S., 1987. Irrigation of field crops principles of practices. Published by Indian Council of Agricultural Research, Krishi Anusandhan Bhavan, Pusa, New Delhi.

Patel, H.R., Patel, R.G and Raman, S. 1988. Response of summer greengram to moisture regimes and nitrogen fertilization. Indian Journal of Agronomy. 33(1): 102-103.

Piper, 1966. Soil and Plant Analysis. Academic Press, New York and Hons Publications, Bombay, pp. 28-46.

Rao, S.R., Pratap Kumar Reddy, A and Sailaja, V. 2012. Yield, yield attributes and economics of chickpea as influenced by varieties and phosphorus levels..). The Andhra Agricultural Journal. 59(4): 527-528. 
Reddy, N.R.N., and Ahlawat, I.P.S. 1998. Response of chickpea (Cicer arietinium L.) genotypes to irrigation and fertilizers under late-sown conditions. Indian Journal of Agronomy. 43(1): 95101.

Roy, R.K., and Tripathi, R.S. 1985. Effect of irrigation and phosphorus on yield, nodulation, water use efficiency and nutrient concentration in chickpea.
Indian Journal of Agronomy. 30(4): 401-406.

Singh, V.K., and Dixit, D.S. 1992. Effect of moisture regimes and sowing date on chickpea (Cicer arietinium L.). Indian Journal of Agronomy. 37(4): 739-743.

Srivastava, G.P., and Srivastava, V.C. 1994. Effect of irrigation and foliar spray of nutrients on growth and seed yield of gram (Cicer arietinium). Indian Journal of Agricultural sciences.64 (4): 219-22.

\section{How to cite this article:}

Swetha, D. and Hussain, S.A. 2017. Effect of Moisture Regimes on Yield Attributes, Yield, Nutrient Uptake and Quality of Chickpea Cultivars (Cicer arietinium L.). Int.J.Curr.Microbiol.App.Sci. 6(9): 3636-3645. doi: https://doi.org/10.20546/ijcmas.2017.609.447 